\title{
Structural and bit-by-bit modeling of the cities
}

\author{
Bauyrzhan Yedilbayev ${ }^{1, *}$, Akmaral Shokanova ${ }^{1}$, Zauresh Akhmetova ${ }^{1}$, Gani Askarov ${ }^{1}$, \\ Nurlan Kalganbayev ${ }^{1}$ \\ ${ }^{1}$ Al-Farabi Kazakh National University, al-Farabi Ave. 71, 050040 Almaty, Republic of Kazakhstan
}

\begin{abstract}
Developed economic - ecological model of modern large city on the example of Almaty, based on the main provisions of statistical theory, theories of logistics and the similarity of the General plan of development of Kazakhstan megapolis, the strategy of transport development of Kazakhstan, programs to reduce the traffic load on the highways regulations of international and national importance, as well as on the basis of predictive decisions arising from the comprehensive consideration of the issues city transport road ecology (CTRE). It includes for the first time scientifically grounded ecological and economic indicators and daily ecological model of Almaty which were initial data for further researches and calculations. However, this complex problem practically in all textbooks and manuals on ecology is considered factually, i.e. separately without interrelation, and questions of interrelation or mutual influence of emissions of motor transport in aggregate with infrastructure SRN (traffic lights, intersections, sidewalks, avenues, etc.) on environment are not still considered in the world literature. Besides there are no data on distribution of exhaust gases (EG) of motor vehicle in the residential area near highways in any source. Therefore, even it is difficult to expert to define the main sources of pollution of urban air environment.
\end{abstract}

\section{Introduction}

Considering this question is necessary for the analysis of an ecological condition in the city and justification of prospects of its development. Thus known parameters were used, in the absence of those and existence of the similar, interconnected indicators of the Construction Norms and Regulations of Republic of Kazakhstan and Construction Norms and Regulations of the USSR (still used in Kazakhstan), and also some look-ahead decisions started with provisions of the static theory, the theory of logistics and similarity, the master plan of development of Almaty 20 years ago and now. They were accepted according to category of the population (children, school students, pensioners, and economically active part), nature of activity of inhabitants and a current state of a life of citizens etc.

\section{Methodology}

According to the objectives of the main objects of research is Almaty. However, such a

\footnotetext{
${ }^{*}$ Corresponding author: b.t.yedilbayev@gmail.com
} 
metropolis as a whole is impossible to study. It can be considered from the position of structural-element approach proposed by academician of NAS RK Balabekov O. S. and developed by his students. According to this theory, one characteristic element of an object with a known structure is investigated and, having determined the parametric relationship of a set of elements, it is possible to establish General laws of functioning of the object under consideration.

According to this methodology, the residential area of any city or locality should be considered along the chain: a residential building with pedestrian paths; a yard surrounded by residential buildings; a microdistrict (quarter) with access roads; a residential area; a city. Motor transport is studied in sequence: as a single car; cars moving in one lane after another or in a row on a multi-lane road in parallel, flow, and SRN - as part of the highway, limited by traffic lights.

Table 1. The number and structure of motor vehicle (for the beginning of year), one thousand units.

\begin{tabular}{|c|c|c|c|c|c|c|}
\hline & 2004 & 2005 & 2006 & $2007 *$ & 2018 & 2019 \\
\hline $\begin{array}{l}\text { Republic of Kazakhstan } \\
\text { Including categories: }\end{array}$ & 1532.3 & 1752.6 & 1807.7 & $2000-2190$ & 3846 & 3698 \\
\hline A-automobile & 1204.1 & 1405.3 & 1404.6 & & & \\
\hline B-buses & 62.9 & 65.7 & 72.3 & & & \\
\hline L-lorries & 224.9 & 281.5 & 282.0 & & & \\
\hline Almaty & 235.9 & 289.3 & 340 & $410-420$ & 476 & 466 \\
\hline A & 199.5 & 254.8 & 287.3 & $344-353$ & & \\
\hline B & 9.6 & 8.1 & 11.6 & $17-18$ & & \\
\hline $\mathrm{L}$ & 23.0 & 26.4 & 41.1 & $49-50$ & & \\
\hline Astana & 75.5 & 89.9 & & $150-160$ & & 264,9 \\
\hline A & 60.0 & 77.7 & & & & \\
\hline B & 3.3 & 2.7 & & & & \\
\hline $\mathrm{L}$ & 10.3 & 9.5 & & & & \\
\hline Almaty region & 171.1 & & & & & 489,2 \\
\hline A & 127.0 & & & & & \\
\hline B & 5.7 & & & & & \\
\hline $\mathrm{L}$ & 38.4 & & & & & \\
\hline South Kazakhstan region & 127.7 & 150.7 & & & & 344,3 \\
\hline A & 98.6 & 121.7 & & & & \\
\hline B & 8.3 & 8.5 & & & & \\
\hline $\mathrm{L}$ & 18.3 & 20.6 & & & & \\
\hline \multicolumn{7}{|l|}{ Note: } \\
\hline $\begin{array}{l}\text { Data of Traffic police of } \\
* \text { Look-ahead assessment }\end{array}$ & $\begin{array}{l}\text { nd Aki } \\
\text { bwn) }\end{array}$ & $\mathrm{cal}$ at & of $A$ & & & \\
\hline
\end{tabular}

For example:

- while defining the population of Almaty it is noted that 1.3 million people constantly live in the city, 230 thousand students (60-70\% of them are nonresident as they are part-time students), 50-60 thousand people come daily, 60-70 thousand people work temporarily (construction, trade) and live without a registration and also dynamics of birth rate and mortality on age were taken into consideration. Thus, daily population makes more than 1.5 million people. It is confirmed by the look-ahead data of Almaty akimat; 
- the number of motor vehicles is defined from table 1.5 and on the account that $97 \%$ of cars individual, according to the statistics theory only $2 / 3$ part of them (repair, because of high cost of gasoline public transport is cheaper, because of constant jams it is quicker and more usefully on foot, some families have 2-3 cars, the personal car and so forth), and from trucks and buses taking into account data on a passenger turnover and goods turnover only 85-90 \% leave places of parking on the road. Thus, as it was noted in the previous section, 55-70 thousand motor vehicles drive daily in Almaty, more than 900 of them are nonresident buses. There are 1400 ambulance calls, 8-10 thousand taxi and private carriers daily in the city. Thus, we will receive that nearly 340 thousand units of cars are on highways of the city and they define intensity of movement of cars at rush hours and cause jams. This indicator is not predicted by Almaty akimat and is not defined;

- an assessment of conditional foodstuff carried out taking into account age categories, and also a way of life of the person. Almaty is the financial, educational and cultural center of Kazakhstan. Therefore, its inhabitants generally carry out an inactive way of life. Daily consumption of products by children of preschool age and pupils of schools on the established norms makes 1000-1700g. The volume eaten by the adult person depending on his anthropometrical data and nature of labor activity is equal to $2,5-3,0 \mathrm{~kg}$. Calculations showed that for an average person in Almaty this indicator equals to $2.56 \mathrm{~kg}$;

- at determination of providing population with housing in Almaty started with conditions of environmental friendliness of houses (buildings), i.e. from comfort of stay in them which indicators are given in Table 2.

Table 2. Indicators of comfortable staying of the person in a house.

\begin{tabular}{l|c|c}
\hline \multicolumn{1}{c|}{ Indicators } & \multicolumn{2}{c}{ Seasons of the year } \\
\cline { 2 - 3 } & Cold & Warm \\
\hline Air temperature, C & $20-22$ & $22-25$ \\
Mobility of air, m/s & $0.1-0.15$ & $0.15-0.25$ \\
Humidity of air, \% & $30-45$ & $30-60$ \\
Differences of temperature, C: & & \\
-between a wall and air of rooms & $2-3$ & - \\
-between a floor and air of rooms & 1.5 & - \\
& & \\
Air volume on one person, m3/people, at single air exchange: & & \\
-in living rooms and kitchens with electric stoves or 2 burners' gas & 60 & 60 \\
stoves; & 90 & 90 \\
-with gas stoves with 4 burners; & 25 & 25 \\
-in lavatories & $1000-3000$ & $1000-3000$ \\
Concentration of easy ions in air, an ion/cm 3 & $10-40$ & $10-40$ \\
Concentration of ozone in air, mkg/m $3 \mathrm{~m}^{3}$ & & \\
\hline
\end{tabular}

However, the universal use of plastic windows in it which because of high density reduce mobility and an air exchange isn't considered. Therefore, the air volume for one person in a living room is increased by us to $15-20 \%$. This transfer can be continued. Thus, developing ecological and economic indicators of Almaty (Table 3) were based on strict scientifically reasonable methodology.

For the first time the developed ecological and economic indicators are basic data for research and calculation of an ecological situation of any settlement. There is no such group of data not only in Almaty, but also in other cities.

Scientific and practical value of the developed indicators will be confirmed in further researches. Here we will show the general model of an ecological condition in Almaty (Table 4). 
Table 3. Ecological and economic indicators of Almaty for the beginning of 2010.

\begin{tabular}{|c|c|c|c|c|c|}
\hline № & Indicators & $\begin{array}{l}\text { Values of } \\
\text { indicators }\end{array}$ & $\begin{array}{c}\text { Standard } \\
\text { (rational) values }\end{array}$ & Excess & Deficiency \\
\hline 1 & Territory, thousand hectares, & 31.9 & & & \\
\hline 1.1 & $\begin{array}{l}\text { The area of the planted trees and shrubs } \\
\text { territories }\end{array}$ & 4.0 & 14.2 & & 10.2 \\
\hline 1.2 & Total area of mirrors of water fund & 1.12 & & & \\
\hline 2 & Population, million people, including. & $1.3(1.5)$ & 0.8 & 0.7 & \\
\hline 2.1 & Economically active population: & 0.650 & & & \\
\hline 2.2 & Pupils & 0.175 & & & \\
\hline 2.3 & Students & 0.230 & & & \\
\hline 2.4 & Pensioners & 0.360 & & & \\
\hline 3 & $\begin{array}{l}\text { Population density, thousand } \\
\text { people/hec }\end{array}$ & 40.7 & 25.1 & 15.6 & \\
\hline 4 & Average providing the population with & 22 & $32-37 *$ & - & 10.15 \\
\hline 5 & housing, $\mathrm{m}^{2} /$ person & $420(500)$ & 270 & 150(230) & \\
\hline 6 & Number of motor vehicles, thousand & 120 & 420 & & 300 \\
\hline 7 & $\begin{array}{l}\text { Number of parking spaces (cars), } 1000 \\
\text { Density of highways with a firm }\end{array}$ & 5.3 & 2.4 & 2.9 & \\
\hline 8 & covering & $13(16)$ & 8.5 & $4.5(7.5)$ & \\
\hline 9 & $\mathrm{~km} / \mathrm{sq} \mathrm{km}$ & 54 & 130 & & 76 \\
\hline 10 & Transport density, units/hectares & & & & \\
\hline 10.1 & Major maintenance of roads, $\mathrm{km} / \mathrm{year}$ & 13 & & & \\
\hline 10.2 & Daily consumption: & 45 & & & \\
\hline 10.3 & Electricity, mln. kw/hour & 1.4 & & & \\
\hline 10.4 & heat, thousand Gcal & 700 & & & \\
\hline 10.5 & gas, million cubic meter & 420 & & & \\
\hline 10.6 & $\begin{array}{l}\text { cold water, million cubic meter } \\
\text { bread, ton }\end{array}$ & 3.0 & & & \\
\hline 11 & $\begin{array}{l}\text { automobile gasoline and diesel fuel, } \\
\text { thousand t }\end{array}$ & 850 & 800 & 50 & \\
\hline 12 & $\begin{array}{l}\text { Passenger turnover in public transport, } \\
\text { thousand people per day }\end{array}$ & $60-70$ & - & $60-70$ & \\
\hline 13 & Number of the registered road accidents & & & & \\
\hline 13.1 & per day & 460 & - & 460 & \\
\hline 13.2 & Every day HS jump out environment: & 1400 & - & 1400 & \\
\hline 13.3 & in the atmosphere, $\mathrm{t}$ & 815 & - & 815 & \\
\hline 14 & firm household waste, $\mathrm{t}$ & 1400 & - & 1400 & \\
\hline 15 & $\begin{array}{l}\text { sewage, thousand cubic meter } \\
\text { call of ambulance, time } \\
\text { Arrive in hospital, person }\end{array}$ & 660 & - & 660 & \\
\hline \multicolumn{6}{|c|}{$\begin{array}{l}\text { Note: } \\
\text { *Buildings with plastic windows; } \\
\text { ()- nonresidents of the city }\end{array}$} \\
\hline
\end{tabular}

From this model we can see that Almaty does not give anything useful to environment; on the contrary, it takes everything and thus pollutes environment in huge scales [1].

Table 4. Ecological model of Almaty.

Thousand units per day

\begin{tabular}{l|l|c|c|c}
\hline № & \multicolumn{1}{|c|}{ Component or resource name } & $\begin{array}{c}\text { Consumption } \\
\text { by the city }\end{array}$ & $\begin{array}{c}\text { Made in } \\
\text { the city }\end{array}$ & $\begin{array}{c}(-) \text { deficiency } \\
(+) \text { excess }\end{array}$ \\
\hline 1 & $\begin{array}{l}\text { Consumption of oxygen of the air pool }(\mathrm{t}), \\
\text { including: }\end{array}$ & 115 & 0.7 & -114.3 \\
\hline
\end{tabular}




\begin{tabular}{l|l|c|c|c}
\hline 1.1 & inhabitants and visitors & 7.0 & & \\
1.2 & motor transport & 10.0 & & \\
1.3 & $\begin{array}{l}\text { Combined heat and power plant, industrial } \\
\text { enterprises }\end{array}$ & 98 & & \\
\hline 2 & Water use (cubic meters), incl.: & 700 & & -700 \\
2.1 & $\begin{array}{l}\text { for economic and drinking needs of the } \\
\text { population }\end{array}$ & $400-450$ & & \\
\hline 3 & Consumption of conditional foodstuff (t), incl.: & 3.84 & & -3.84 \\
\hline 3.1 & Bread & 0.42 & & \\
4 & Consumption of conditional fuel (t) & 37 & & -37 \\
4.1 & For motor transport & 3 & 816.86 & +816.86 \\
5 & HS emissions in environment (t) & & 0.72 & \\
5.1 & In atmosphere & & 815 & \\
5.2 & superficial sewage & & 1.4 & \\
5.3 & firm household waste & & \\
\hline
\end{tabular}

For an evident ecological assessment of influence of the city, we will enter an equivalent in the form of the earth area. For example, for compensation of deficiency of 114.3 thousand oxygen it is necessary to plant the wood with the area of 823 thousand hectares, and for receiving 3.84 thousand $t$. of conditional foodstuff it is necessary in an equivalent on wheat 700 thousand hectares of the earth without work of producers - agricultural workers and workers for preparation of food to a final stage. It is similarly possible to execute the same calculations for water, completion of other types of the resources consumed by the city. The same is with raw materials for the industry and the enterprises of construction materials. Besides there is lack of territory for dispersion of emissions of harmful substances (HS) in the atmosphere, the air pool and storages of a firm waste. Thus, recognized that impurity of Almaty exceeds on the average 2-3 times of maximum-permissible concentration (maximum concentration limit) [2-4].

Summarizing the areas of the territory of the earth and a surface of mirrors of water fund on each indicator received nearly 3,0 million hectares of the earth necessary for independent functioning of Almaty, and it is 94 times more than the present territory of the Kazakhstan megalopolis.

The city of Almaty is the largest urbanized center of Kazakhstan. However, development and city industrialization without the sufficient accounting of physical, geographical and climatic features and ecological requirements led to ecological disruption in the megalopolis territory.

Average air temperature of Almaty $+8,9{ }^{\circ} \mathrm{C}$ (during the warm period $+28,2^{\circ} \mathrm{C}$, the cold period- $11{ }^{\circ} \mathrm{C}$ ), barometric pressure $920 \mathrm{GPa}$, the prevailing direction of a wind - southern. Settlement geographic latitude is $44^{0} \mathrm{NL}$. The northern point of Almaty has a mark of $670 \mathrm{~m}$ above sea level, and southern $-970 \mathrm{~m}$.

In Almaty, climatic factors create conditions for formation of high pollution of the atmosphere of the city. The city is characterized as light wind, repeatability of light breezes (to $1 \mathrm{~m} / \mathrm{sec}$ ) it is estimated in the summer here at $71 \%$, in the winter in $79 \%$, in a type of it mid-annual value of speed of a wind in the city doesn't exceed $1,7 \mathrm{~m} / \mathrm{sec}$ which was confirmed by us experimental data.

The analysis of orographical conditions of the territory of the megalopolis shows that its vicinities are open in the northern direction on hundreds kilometers, and in the southern surround stretching ridges, and it promotes penetration of air masses into a foothill part where powerful air temperature inversions are formed, especially in the winter. Accumulation of harmful impurity in a ground layer of air is promoted by light breezes, and temperature inversions, which are an obstacle for development of vertical air exchange and diffusion of polluting substances in the atmosphere. 
At all directions of a wind, the city appears in so-called «an aerodynamic shadow». Climatic features create adverse conditions for dispersion of emissions; especially exhaust gases of motor transport and individual sources of heating. The exhaust gases containing oxides of carbon, nitrogen, hydrocarbons, firm particles and compounds of lead collect in a ground layer of the atmosphere. The most part from them settles on an asphalt covering and a soil cover. The dust with a complex of metals and other polluting substances through respiratory organs and skin gets to a human body.

The function of passing of flat winds the system should be fulfilled by avenues, boulevards, recreation areas of the wide orientation main element of which is the recreational zone along the LAC (Large Almaty Channel), and the highways, which are cutting through on a meridian of Almaty, since the party of mountains should carry out function of corridors. However, this ecologically justifiable principle is broken in the last decade because of rash construction of buildings and constructions across the direction of a wind stream both from the South, and from the North. All these led to creation of the manufactured ditch surrounded with the ridge and a technogenic wall in the form of high-rise constructions of the industrial enterprises and multistoried buildings.

Basis of formation of perspective planning structure of the city is the natural and ecological and transport framework. The natural and ecological framework is formed by the mountain, rivers proceeding in the meridional direction through the city, parks, squares, boulevards and other planted trees and shrubs territories, which are city "lungs". As a whole the structure of an ecological framework, is the large meshed grid, consisting their mutually being crossed green corridors of meridian and wide orientation for the admission of air streams mountain valley and flat circulation.

The following element of the urbanized framework of the city is the system of transport highways. The master plan provides development and improvement of transport structure of the city by creation in additions to existing new meridian and wide highways, roundabout highways, a network of service of vehicles, construction of traffic intersections, overpasses, platforms etc. The principle of creation of uniform system of high-speed city roads and highways is put in a basis of development of a street road network with differentiation of the last on highways of continuous and adjustable movement [5-7].

According to tasks of work, the main object of research is Almaty. However, as a whole it is impossible to study such megalopolis. It can be considered from a position of the structural and bit-by-bit approach offered by the academician of NAS RK Balabekov O. S. According to this theory, one characteristic element of object with known structure is investigated and, having defined parametrical interrelation of a set of elements, it is possible to determine the general consistent patterns of functioning of considered object. According to this methodology, the territory intended for building of any city or the settlement should be considered on a chain: a house with footpaths; a yard surrounded with a housing estate; the residential district (quarter) with access roads; residential area; city. Motor transport is studied on sequence: as individual car, the cars moving on one strip one after another or in a row on the multiband road in parallel, a stream, and SRN- as the part of a highway limited to traffic lights.

Here it should be noted that developed in many cities of Kazakhstan the name "residential district" does not correspond to standard terms since these structural objects in reality are dismembered by the main streets and roads. They treat residential areas. Therefore, we will use further the term quarter.

Let us consider structure of Almaty (the drawing 1). According to the basic plan and a designated purpose of town-planning objects at level of cadastral quarters are defined following territorial planning units: 5 planning zones, 50 cadastral districts, 400 cadastral sectors and 8000 cadastral quarters which are the smallest planning unit when developing the plan of functional zoning. 
Thus, on structural bit-by-bit modeling we have system: quarter - sector - the district - a zone - the city. From here follows, if there will be data on an ecological condition of quarter and its functional value in sector, the district, a planning zone, it is possible to argue about ecological model of all city.

Choosing the working object (quarter) the research started with the following requirements:

- typicalness of the chosen inhabited quarter to another on density and number of floors of existing construction, gardening, building by new houses;

- existence in the chosen quarter of highways limiting it and roads with intensity of movement of the motor vehicles similar to the average in Almaty, sidewalks, avenues (boulevards) in the middle of the wide street with specially landed trees and bushes, traffic lights, bus (trolleybus, tram) parking and parking for a taxi;

- the territory of quarter should be only or mainly under negative impact of motor vehicles, i.e. there are no combined heat and power plants, the industrial enterprises, gasdistributing stations and fuel points;

- functioning of stationary posts on supervision over impurity of atmospheric air (PSI) [8-10].

The last requirement is very important, since it allows obtaining objective and authentic data, irrespective of experience and interest of researches, accuracy of used techniques and devices, and their compliance to standard (standard) requirements.

All these requirements are answered by quarter with cadastral number No. K (Figure 1) being in sector of No. of 3802 districts No. 38, since:

- it is surrounded with highways typical for Almaty (Abay Ave. and Seyfullin, Satpayev St.) and (Masanchi St.) road with 2, 4 and 6 lanes (nearly 80-90\% of streets of Almaty) and average intensity of movement of motor vehicle of 2-3 thousand units an hour without road outcomes;

- occupation of the territory mainly by houses;

- existence in quarter of the avenue (Masanchi St.), the planted trees and shrubs strips along streets and roads, domestic gardening, platforms for game of children and daily shortterm rest of inhabitants of quarter, public and scientific institutions (Kazhydromet, post №1);

- an arrangement of a number of establishments of teaching and educational appointment (KazNTU named after K.Satpayev, the Kazakh medical university, Almaty versatile equipment - economic college "UNAT", Kaynar university), a sports complex (stadium of KazNTU), research and design institutes;

- chosen architectural planning city structure does not belong to historical, recreational and landscape and mastered territories. However, it has elements of new building at the expense of the standard decision on consolidation of platforms of the territory of the residential area;

- the studied object does not settle down near mountains and mountain small rivers, but has possibility for the admission of air streams a mountain valley and flat circulation (Seyfullin Avenue) at least on the one hand the presence of badly aired highways (Abay Ave. and Satpayev St.) and the deadlock street (st. Masanchi);

- the chosen quarter does not belong to ecologically adverse or critical zone and is only or mainly under technogenic influence of motor transport since stationary sources of pollution are at considerable distance. Besides, there are no buildings with individual heating with use of coal, liquid or gaseous fuel. Such requirement allows estimating level of pollution of the air pool motor vehicle emissions;

- the chosen quarter does not belong to ecologically adverse or critical zone (the appendix D, the drawing 3) and is only or mainly under technogenic influence of motor transport since stationary sources of pollution are at considerable distance. Besides, there are no buildings with individual heating with use of coal, liquid or gaseous fuel. Such 
requirement allows estimating level of pollution of the air pool automatic telephone exchange emissions;

- the presence of a stationary position to monitor air pollution (PSI) № 1 for sampling and analysis of air. It should be noted that PSI № 12 (Nauyrzbai batyr-Raimbek) is located in the most intensive traffic exchanges, and PSI № 25 (Marecheka-Baurzhan Momyshuly) refers to the district with the lowest traffic density. Results of PSI № 12 and 25 are necessary to assess the reliability of the practical results when compared with the theoretical ones [11$15]$.

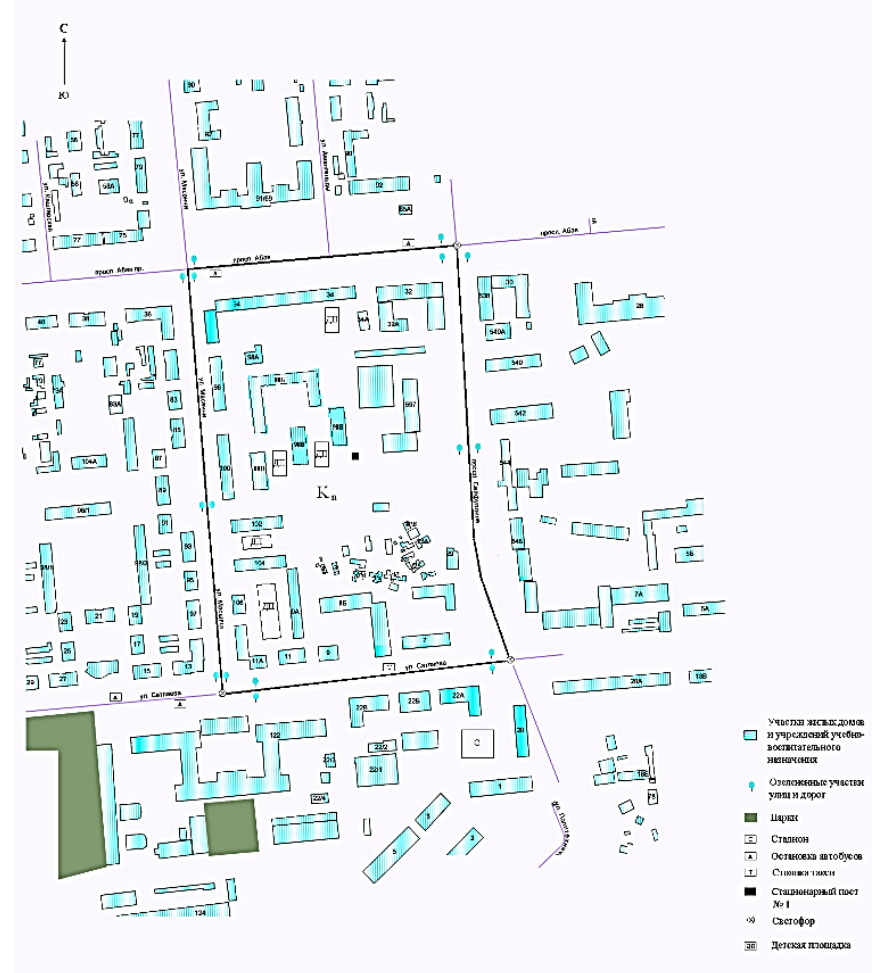

Fig. 1. The map scheme of quarter with cadastral number K.

Typical features for the selected quarter of Almaty can be continued. Nevertheless it started from the fact that, in accordance with the law of the Republic of Kazakhstan "On architectural, town planning and construction activities in the Republic of Kazakhstan" on the reference plane of the functional zoning of the territory within the city limits 9 basic types were established in Almaty.

1. Residential areas -9.5 hectares $(30 \%)$;

2. Social and business zones -2.2 hectares $(7 \%)$;

3. Industrial (manufacturing) zone -2.4 hectares $(7.5 \%)$;

4. Areas of engineering and transport infrastructure -5.5 hectares $(17 \%)$;

5. Zone of agricultural and forestry use -4.6 hectares $(14.5 \%)$; 
6. Reaction zones -2.4 hectares $(7.5 \%)$

7. Special Purpose Zones -0.5 hectares $(1.5 \%)$

8. Secure zone area -0.14 hectares $(0.5 \%)$

9. Incommodious and unused areas requiring special engineering event -4.7 hectares (14.5\%) [10-16].

Quarter's № K as a model element of residential areas bears all features of functional zones № 1, 2, 4 .

While researching we based on these methods:

- a static evaluation of the data of the people who live in that quarter, the bus drivers(buses №92,95.trolley- buses and taxis) and our own observations;

- the use of standard parameters on characteristics of highways (streets and roads), motor vehicles, gasoline and diesel fuel;

- analysis of materials of official sites of Almaty Local authority;

- NSE data "Kazhydromet" on air pollution in Almaty (PSI № 1,12,25);

- model studies in laboratories at the Institute of "Ecology" at the International KazakhTurkish University named after H.A.Yassau [16,17,18, 19].

\section{Conclusion}

Designed ecological-economic model of modern large city on the example of Almaty, based on the main provisions of statistical theory, theories of logistics and the similarity of the General plan of development of Kazakhstan megapolis, the Strategy of transport development of Kazakhstan, programs to reduce the traffic load on the highways regulations of international and national importance, as well as on the basis of predictive decisions arising from the comprehensive consideration of the issues City transport road ecology (CTRE). It includes for the first time scientifically grounded ecological and economic indicators and daily ecological model of Almaty, which were initial data for further researches and calculations.

\section{References}

1. J. Treiterer, J. A. Myers, The hysteresis phenomenon in traffic flow, 13 (D.J. Buckley, Artarmon, New South Wales, 1974)

2. D. Helbing, Rev. Mod. Phys., 73, 1067 (2001)

3. I. Lubashevsky, R. Mahnke, P. Wagner, and S. Kalenkov, Phys. Rev. E., 66, 016117 (2002)

4. I. Lubashevsky, M. Hajimahmoodzadeh, A. Katsnelson, and P. Wagner, Eur. Phys. J., 36, 115 (2003)

5. R. Kuhne, R. Mahnke, I. Lubashevsky, and J. Kaupus, Phys. Rev. E., 65, 066125 (2002)

6. B. S. Kerner, Physics of Traffic (Springer, Berlin, 2004)

7. I. Lubashevsky, P. Wagner, R. Mahnke, Phys. Rev. E., 68, 056109 (2003)

8. I. Lubashevsky, P. Wagner, R. Mahnke, Eur. Phys. J., 32, 243-247 (2003)

9. P. Wagner, I. Lubashevsky, Empirical basis for car-following theory development, eprint Arxiv: cond-mat/0311192

10. J. Krug, H. Spohn, Phys. Rev. A., 83, 4271

11. B. Yedilbayev, A. Shokanova, World Applied Sciences Journal, 25 (5), 699-703 (2013)

12. M. Garavello, P. Goatin. The Cauchy problem at a node with buffer, discrete and continuous dynamical systems (American Institute of Mathematical Sciences, 2012)

13. M. Garavello, A. Piccoli, Multibuffer model for LWR road networks, 143-161 (Springer, New York, 2013) 
14. C. Roncoli, M. Papageorgiou, I. Papamichail, Transp Res Part, 57, 241-259 (2015)

15. B. Yedilbayev, Zh. Kozhamkulova, E3S Web of Conferences, 135, 02011, ITESE,(2019)

16. W-L. Jin, A kinematic wave theory of multi-commodity network traffic flow. Transp. Res. Part, 46, 1000-1022 (2012)

17. D. Onaltayev, A. Kazhmuratova, S. Akhmetkaliyeva, R. Malikova, A. Yelyubayeva, E3S Web of Conferences, 135, 04046 (2019)

18. Akhmetshin, E. M., Sekerin, V. D., Pavlyuk, A. V., Shichiyakh, R. A., \& Allanina, L. M. Theoretical and Empirical Researches in Urban Management, 14(2), 5-19. (2019).

19. Mutanov, G., Ziyadin, S. /E3S Web of Conferences -2019-135,04056 , DOI: $10.1051 / \mathrm{e} 3$ sconf/201913504056 (2019) 